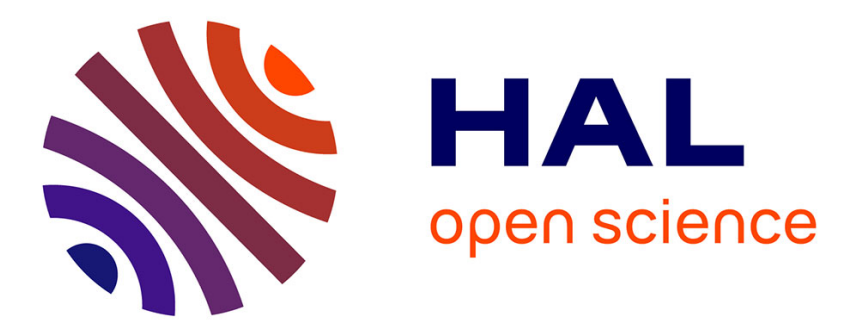

\title{
Perfect reversibility of the lithium insertion in FeS2: the combined effects of all-solid-state and thin film cell configurations
}

Vincent Pelé, Florian Flamary, Lydie Bourgeois, Brigitte Pecquenard, Frédéric Le Cras

\section{- To cite this version:}

Vincent Pelé, Florian Flamary, Lydie Bourgeois, Brigitte Pecquenard, Frédéric Le Cras. Perfect reversibility of the lithium insertion in FeS2: the combined effects of all-solid-state and thin film cell configurations. Electrochemistry Communications, 2015, 51, pp.81-84. 10.1016/j.elecom.2014.12.009 . hal-01101776

\author{
HAL Id: hal-01101776 \\ https://hal.science/hal-01101776
}

Submitted on 22 Jul 2015

HAL is a multi-disciplinary open access archive for the deposit and dissemination of scientific research documents, whether they are published or not. The documents may come from teaching and research institutions in France or abroad, or from public or private research centers.
L'archive ouverte pluridisciplinaire HAL, est destinée au dépôt et à la diffusion de documents scientifiques de niveau recherche, publiés ou non, émanant des établissements d'enseignement et de recherche français ou étrangers, des laboratoires publics ou privés. 


\title{
Perfect reversibility of the lithium insertion in $\mathrm{FeS}_{2}$ : The combined effects of all-solid- state and thin film cell configurations
}

\author{
V. Pelée ${ }^{\mathrm{a}, \mathrm{b}, \mathrm{c}}$, F. Flamary ${ }^{\mathrm{a}, \mathrm{b}, \mathrm{c}}$, L. Bourgeois $^{\mathrm{d}}{ }^{\text {, B. Pecquenard }}{ }^{\mathrm{a}}$, F. Le Cras ${ }^{\mathrm{b}, \mathrm{c}}$ \\ ${ }^{a}$ CNRS, Univ. Bordeaux, ICMCB, UPR 9048, F-33600 Pessac, France \\ ${ }^{\mathrm{b}}$ Univ. Grenoble Alpes, F-38000 Grenoble, France \\ ${ }^{c}$ CEA, LETI, Minatec Campus, 17 rue des Martyrs, F-38054 Grenoble cedex, France \\ ${ }^{\mathrm{d}}$ Univ. Bordeaux, CNRS, ISM, UMR 5255, Talence F-33405, France
}

a b s t r a c t

\begin{abstract}
All-solid-state thin film batteries based on sputtered pyrite electrodes, a lithium phosphorus oxynitride electrolyte and a lithium anode were prepared and characterized. The successive reduction of both $\mathrm{S}^{2-}$ and $\mathrm{Fe}^{2+}$ species led to an impressive volumetric discharge capacity, five times higher than the one for $\mathrm{LiCoO}_{2}$. Excellent reversibility and capacity retention were obtained during the first and the subsequent 800 charge-discharge cycles. A continuous cycling in the low voltage domain was found to be detrimental to the reversibility of the conversion reaction, suggesting a progressive evolution of the phase distribution inside the electrode. The initial capacity was easily recovered after few full oxidation cycles.
\end{abstract}

\section{Introduction}

The continuous miniaturization of electronic devices and the emerging need for self-powered miniaturized systems (stand-alone sensors, medical implants, MEMS,...) boost the development of miniaturized energy storage solutions such as all-solid-state thin film batteries (i.e. microbatteries). Up to now, most studies on cathodes focused on intercalation compounds $\left(\mathrm{LiCoO}_{2}, \mathrm{LiMn}_{2} \mathrm{O}_{4}, \mathrm{~V}_{2} \mathrm{O}_{5}, \ldots\right)$, despite their limited capacity $\left(650-1150 \mathrm{~mA} \mathrm{~h} \cdot \mathrm{cm}^{-3}\right)[1,2]$.

Nevertheless, other materials reacting with lithium according to a conversion reaction described by the general formula $\mathrm{M}_{\mathrm{a}} \mathrm{X}_{\mathrm{b}}+(\mathrm{b} \cdot \mathrm{n})$ $\mathrm{Li} \leftrightarrow \mathrm{aM}+\mathrm{bLi}_{\mathrm{n}} \mathrm{X}(\mathrm{M}=$ metal; $\mathrm{X}=\mathrm{O}, \mathrm{N}, \mathrm{F}, \mathrm{S}, \mathrm{P}, \mathrm{H})$ are promising [3] Among them, pyrite $\left(\mathrm{FeS}_{2}\right.$ or $\left.\mathrm{Fe}^{2+} \mathrm{S}_{2}^{2-}\right)$ is an attractive material due to its high capacity of $894 \mathrm{~mA} \mathrm{~h} \cdot \mathrm{g}^{-1}$ (or) delivered around $1.5 \mathrm{~V} \mathrm{vs} \mathrm{Li} / / \mathrm{Li}$ and corresponding to the overall electrochemical reaction $\mathrm{FeS}_{2}+$ $4 \mathrm{Li}^{+}+4 \mathrm{e}^{-} \rightarrow \mathrm{Fe}+2 \mathrm{Li}_{2} \mathrm{~S}$. Given its density of $5.01 \mathrm{~g} \cdot \mathrm{cm}^{-3}$, its volumetric capacity, which is a more relevant criterion for microbatteries than the specific capacity, theoretically reaches $4450 \mathrm{~mA} \mathrm{~h} \cdot \mathrm{cm}^{-3}$. Hence, this value is even higher than the one for elemental sulfur $\left(3460 \mathrm{~mA} \mathrm{~h} \cdot \mathrm{cm}^{-3}\right)$. Several mechanisms have been proposed to describe the reduction of pyrite in batteries with the formation of intermediate compounds which is temperature dependent [4], the final stage being the formation of nanosized iron domains surrounded by a $\mathrm{Li}_{2} \mathrm{~S}$ matrix. At room temperature, pyrite is not recovered upon oxidation, instead either a blend of pyrrhotite $\mathrm{Fe}_{1}-{ }_{\mathrm{x}} \mathrm{S}$ and elemental sulfur $[5,6]$ or a $\mathrm{Fe}^{3+}\left(\mathrm{S}^{2-}\right)\left(\mathrm{S}_{2}^{2-}\right)_{0.5}$ material [7] is formed.

Despite its high specific capacity, the use of pyrite in commercial systems is confined to lithium primary cells and thermal batteries. As for lithium-sulfur cells, the main phenomenon hindering the cycle life lies in the formation of polysulfides which are soluble in the liquid electrolyte. Hence, a way to solve this problem consists in using a solid electrolyte, as recently demonstrated by Yersak et al., in bulk solid-state batteries leading to a reversible capacity higher than $700 \mathrm{~mA} \mathrm{~h} \cdot \mathrm{g}^{-1}$ at $30{ }^{\circ} \mathrm{C}$ during 20 cycles [6].

Only few studies were conducted on the electrochemical behavior of iron sulfide thin films [8-10]. Siyu et al. reported a rather fast capacity loss in liquid electrolyte for sol-gel prepared $\mathrm{FeS}_{2}$ films [9]. Strauss et al. highlighted the better capacity retention of sputtered thin films ( $0.9 \mu \mathrm{m}$ thick) when tested in polymer electrolytes at $125{ }^{\circ} \mathrm{C}$, with a capacity $\left(\sim 1750 \mathrm{~mA} \mathrm{~h} \cdot \mathrm{cm}^{-3}\right)$ remaining far below the theoretical value [10].

This study reports for the first time on the preparation and the electrochemical characterization of complete all-solid-state thin film batteries comprising pyrite sputtered thin film as positive electrode. The awaited benefits of an all-solid-state configuration and of the thin film planar geometry on the course of this 'four electron' electrochemical reaction are investigated. 


\section{Experimental}

$\mathrm{FeS}_{2}$ thin films were prepared by radiofrequency magnetron sputtering (Plassys) from a homemade 2" $\mathrm{FeS}_{2}$ (Alfa Aesar, 99.9\%) target in a pure argon atmosphere at a total pressure of $1 \mathrm{~Pa}$ and an applied power of $1.27 \mathrm{~W} \cdot \mathrm{cm}^{-2}$, without intentional heating of the substrate. Prior to the introduction of the sputtering gas, the pressure in the chamber was reduced below $6 \cdot 10^{-5} \mathrm{~Pa}$.

Chemical analysis was performed on an Electron Probe X-ray Micro Analyzer (EPMA) using a CAMECA SX 100 Bruker AXS spectrometer.

$\mathrm{X}$-ray diffraction measurements were achieved on a Bruker D8 Advance diffractometer either in Bragg-Brentano or in grazing incidence $\left(0.2^{\circ}\right)$ geometry.

Raman scattering measurements were performed with a Horiba Jobin Yvon Labram HR-800 micro-spectrometer. Spectra were recorded

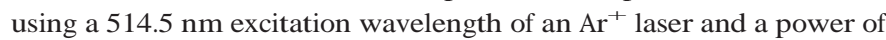
$50 \mu \mathrm{W}$.

All-solid-state cells $\left(25 \mathrm{~mm}^{2}\right)$ were prepared through the successive deposition of the following patterned thin films: current collector $(250 \mathrm{~nm}), \mathrm{FeS}_{2}$ positive electrode $(365 \mathrm{~nm}), \mathrm{LiPON}$ vitreous solid electrolyte $(1400 \mathrm{~nm})$, and a lithium negative electrode $(3000 \mathrm{~nm})$ on a passivated silicon wafer, as reported elsewhere [11]. Finally the cells were protected using a glass cover and a paraffin sealant. The ionic conductivity of the LiPON electrolyte was $2.10^{-6} \mathrm{~S} \cdot \mathrm{cm}^{-1}$ at $25{ }^{\circ} \mathrm{C}$. All electrochemical characterizations were carried out in air at $25{ }^{\circ} \mathrm{C}$ using a VMP3 galvanostat-potentiostat (Bio-Logic). For these thin film electrodes embedded in solid state stacks, as only their volume can be measured, their weight $(\sim 37 \mu \mathrm{g})$, then their specific capacity were estimated from electrochemical measurements carried out in liquid electrolyte (EC:DMC 1:1, $\mathrm{LiPF}_{6} 1 \mathrm{M}$ ) with weighted $\mathrm{FeS}_{2}$ thin film electrodes deposited on aluminum foils.

\section{Results and discussion}

The chemical analysis of iron sulfide films by EPMA measurements leads to a composition of $\mathrm{FeS}_{1.9}$ close to $\mathrm{FeS}_{2}$. The XRD pattern of the thin film (Fig. 1a) demonstrates the direct formation of a pure crystallized pyrite phase at room temperature, with a cubic cell parameter a $=$

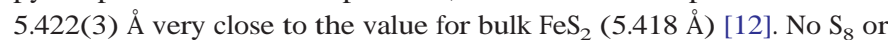
pyrrhotite impurities initially present in the target were detected in the film. The lower relative intensity of the (002) reflection probably highlights a preferred orientation of the (001) planes perpendicular to the substrate. Raman scattering also confirms the $\mathrm{FeS}_{2}$ nature and the pyrite structure. The spectrum (Fig. 1b), similar to the $\mathrm{FeS}_{2}$ powder one, is dominated by 3 narrow bands characteristic of a well-crystallized $\mathrm{FeS}_{2}$ pyrite phase, at ca. $343 \mathrm{~cm}^{-1}\left(\mathrm{E}_{\mathrm{g}}\right.$ mode), $379 \mathrm{~cm}^{-1}\left(\mathrm{~A}_{\mathrm{g}}\right)$ and $430 \mathrm{~cm}^{-1}\left(\mathrm{~T}_{\mathrm{g}}\right)$, in agreement with literature (note that 5 Raman-active modes $\mathrm{A}_{\mathrm{g}} \oplus \mathrm{E}_{\mathrm{g}} \oplus 3 \mathrm{~T}_{\mathrm{g}}$ are predicted by the factor group theoretical analysis of the $\mathrm{FeS}_{2}$ pyrite structure but $2 \mathrm{~T}_{\mathrm{g}}$ modes are expected at 350 and $377 \mathrm{~cm}^{-1}$ in close vicinity of the intense $\mathrm{E}_{\mathrm{g}}$ and $\mathrm{A}_{\mathrm{g}}$ bands) [13].

The cross section view of a $560 \mathrm{~nm}$ thick film (Fig. 1c) clearly exhibits a columnar growth and nevertheless a quite dense morphology, the density being equal to $91 \%$ of the theoretical one. The electrical conductivity of the film, measured by the four-probe method, is about $51 \mathrm{~S} \cdot \mathrm{cm}^{-1}$ at $25^{\circ} \mathrm{C}$ which is significantly higher than for bulk $\mathrm{FeS}_{2}$ or $\mathrm{FeS}_{2}$ thin films obtained by sulfidation of iron [14] and is likely to be induced by both intrinsic defects and the presence of oxygen traces [15]. Afterwards, such pyrite thin films were also patterned on current collectors using a shadow mask (Fig. 1d), integrated in allsolid-state cells (active area $0.25 \mathrm{~cm}^{2}$ ) and then electrochemically characterized.

At low current density, the first reduction of the pyrite film occurred in three distinct stages: (i) a short step between 2.3 and $1.8 \mathrm{~V} \mathrm{vs} \mathrm{Li}^{+} / \mathrm{Li}$, (ii) a marked plateau at $1.7 \mathrm{~V} \mathrm{vs} \mathrm{Li}^{+} / \mathrm{Li}$ and (iii) a final plateau around $1.5 \mathrm{~V} \mathrm{vs} \mathrm{Li}^{+} / \mathrm{Li}$ (Fig. 2a). The two latter involving each about half of the total capacity are consistent with the processes described in literature for bulk $\mathrm{FeS}_{2}$, i.e. a first insertion step corresponding to the reduction of disulfide species into sulfide and leading to the formation of a ' $\mathrm{Li}_{2} \mathrm{FeS}_{2}$ ' compound and a second step corresponding to the reduction of iron through a conversion reaction [4]. The total delivered capacity is then close to $335 \mathrm{~mA} \mathrm{~h} \cdot \mathrm{cm}^{-3}\left(830 \mathrm{~mA} \mathrm{~h} \cdot \mathrm{g}^{-1}\right)$, i.e. $80 \%$ of the theoretical volumetric capacity, this difference being mainly due (a)
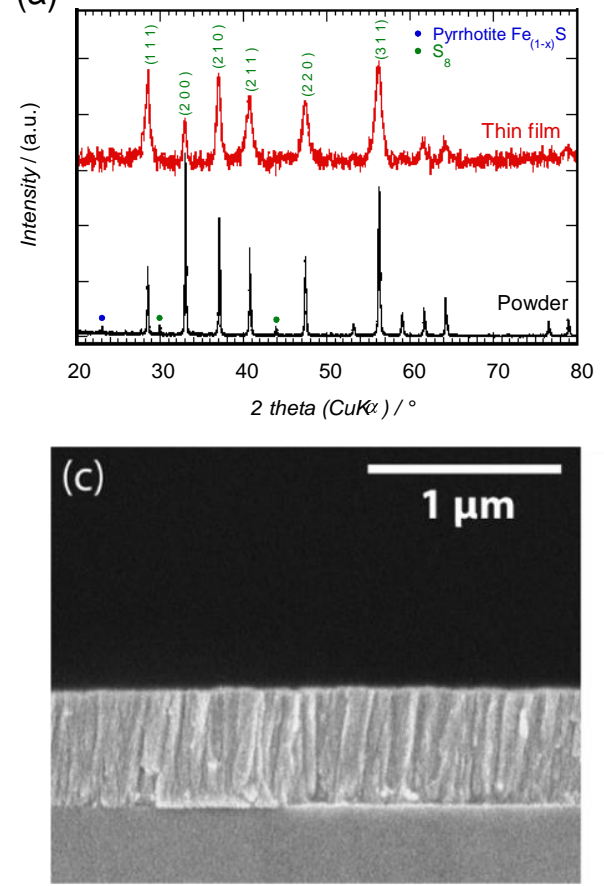

(b)
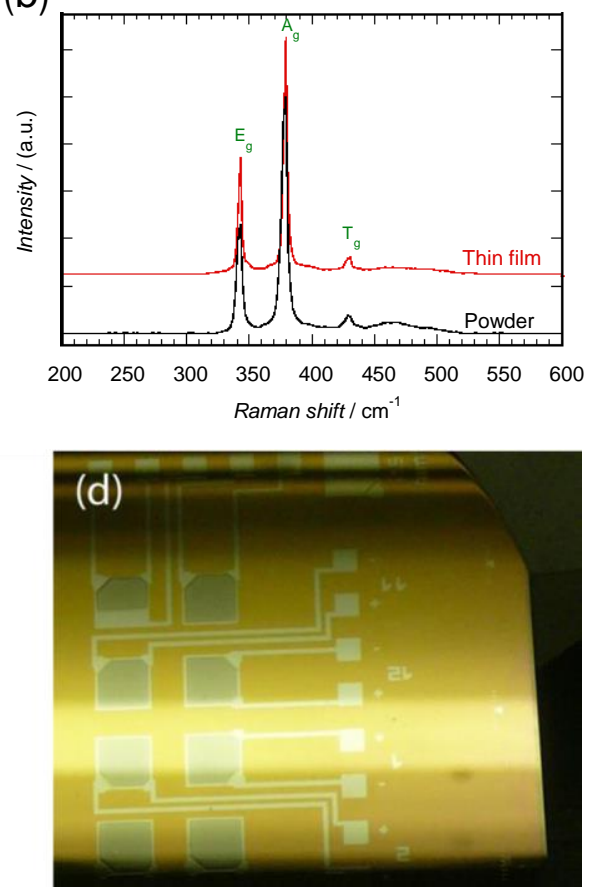

Fig. 1. Comparison of (a) XRD patterns and (b) Raman spectra of the $\mathrm{FeS}_{2}$ powder and the FeS2 thin film. (c) SEM cross section of a pyrite thin film deposited on a silicon wafer, and (d) $25 \mathrm{~mm}^{2}$ positive electrodes deposited on current collectors (first levels of the solid-state microbattery stack). 
(a)

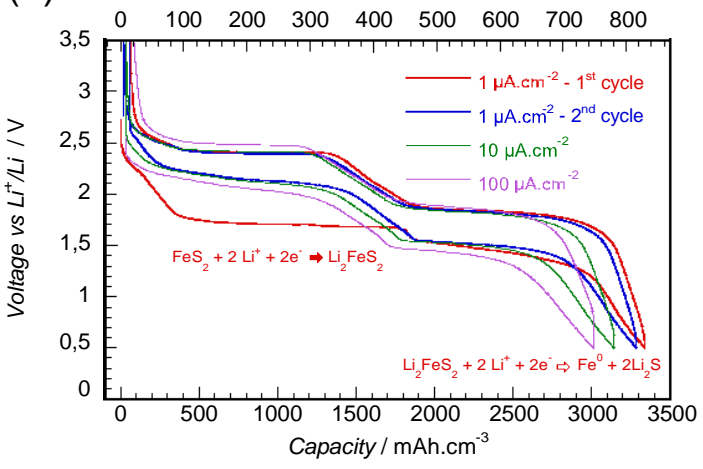

(b)

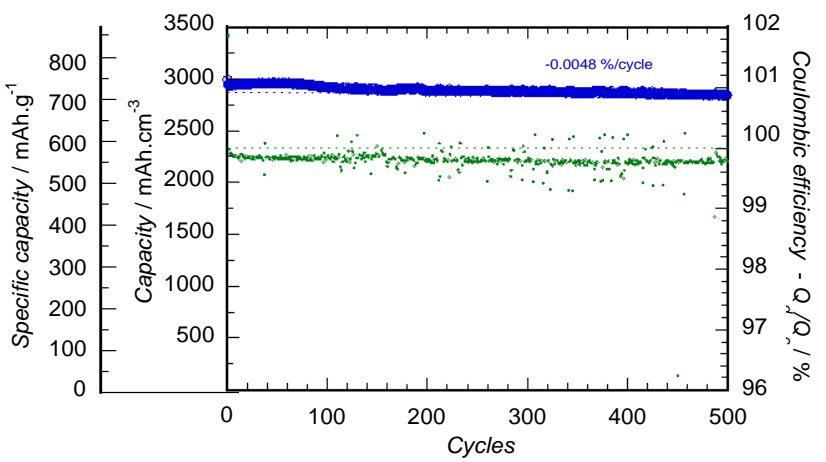

Fig. 2. (a) Voltage curves measured at various constant current densities, and (b) evolution of the thin film capacity during prolonged cycling at $100 \mu \mathrm{A} \cdot \mathrm{cm}^{-2}$ between 0.5 and $3.5 \mathrm{~V}$.

to the lower density of the thin film and a lower thickness of $\mathrm{FeS}_{2}$ thin film near the edges of the pattern due to shadowing effects.

During the first charge, $98.2 \%$ of the inserted lithium is removed from the electrode during two reactions at 1.8 and $2.4 \mathrm{~V} \mathrm{vs} \mathrm{Li}^{+} / \mathrm{Li}$. During the subsequent discharges, two well-defined plateaus are present at 2.14 and $1.5 \mathrm{~V} \mathrm{vs} \mathrm{Li}^{+} / \mathrm{Li}$. Hence, the first stage of the second reduction takes place $0.4 \mathrm{~V}$ above the position of its counterpart during the first reduction. This was attributed in the literature to the formation of a compound different from the pristine pyrite $\mathrm{Fe}^{2+} \mathrm{S}_{2}^{2-}$ at the end of the charge: $\left(\mathrm{Fe}_{1-}{ }_{\mathrm{x}} \mathrm{S}+\mathrm{S}\right)$ or $\mathrm{Fe}^{3+}\left(\mathrm{S}^{2-}\right)\left(\mathrm{S}_{2}^{2-}\right)_{0.5}[5-7]$. The present results are fully consistent with the formation of a new compound with an unchanged overall composition at the end of the charge, and clearly highlight the overall reversibility of the lithium insertion. The suppression of polysulfide dissolution and the minimization of the lithium diffusion paths in all-solid-state thin film cells lead to an excellent electrochemical behavior, with a limited voltage hysteresis even at high regime (Fig. 2a) and an excellent reversibility. Then, the microbattery delivers $565 \mu \mathrm{W} \mathrm{h} \cdot \mathrm{cm}^{-2}$ (per $\mu \mathrm{m}$ of positive electrode) and its mean discharge voltage is $1.75 \mathrm{~V}$.

The cycle life was assessed using a higher current density $\left(100 \mu \mathrm{A} \cdot \mathrm{cm}^{-2}, 1.2 \mathrm{C}\right.$ rate) in the full voltage window between 0.5 and $3.5 \mathrm{~V} \mathrm{vs} \mathrm{Li}^{+} /$Li during 500 cycles (Fig. 2b). The capacity retention was also found to be excellent with a fading of only $-0.0048 \% /$ cycle. As for silicon thin film electrodes, the huge volume expansion of the electrode material during lithium insertion $(\sim+180 \%)$ has no marked detrimental effect on its cycle life in all-solid-state microbatteries [16]. (a)

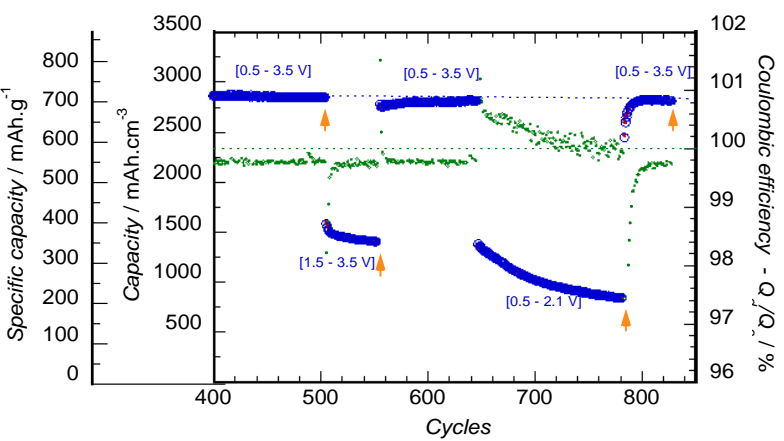

(c)

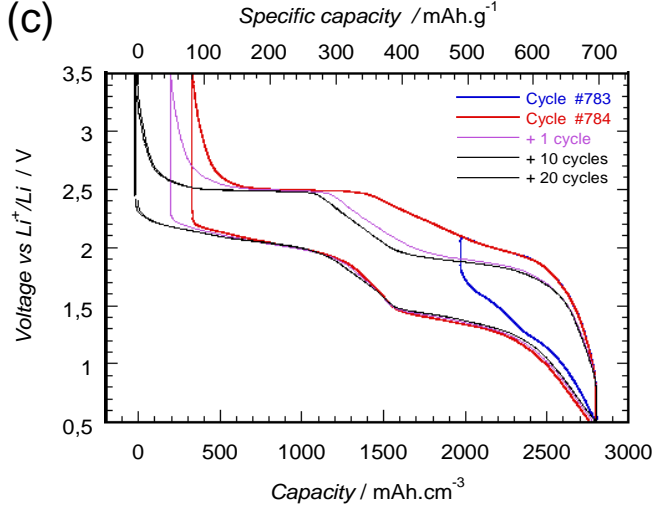

(b) Specific capacity /mAh.g ${ }^{-1}$

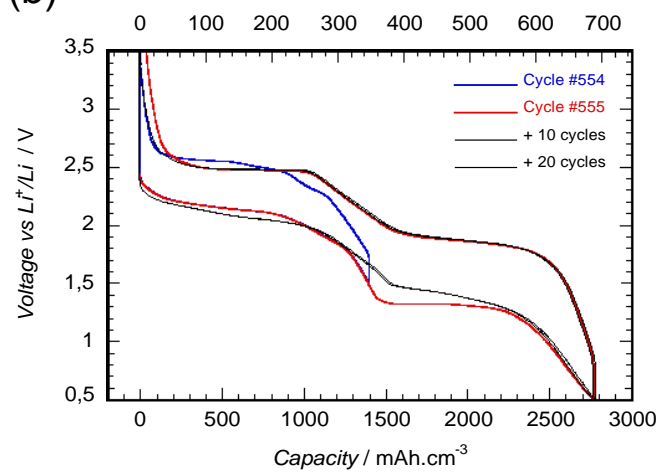

(d)

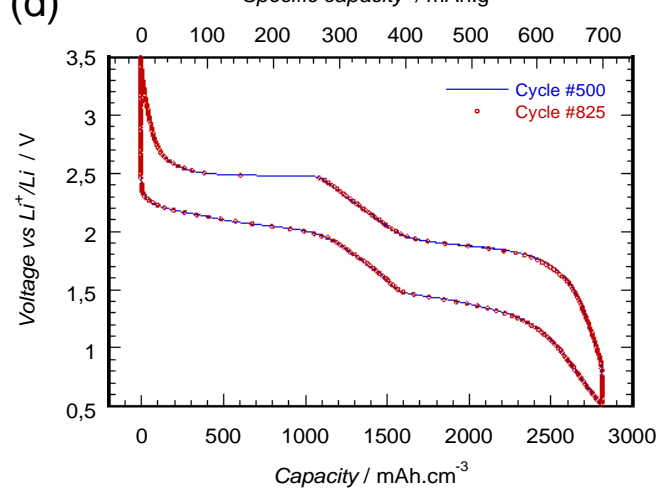

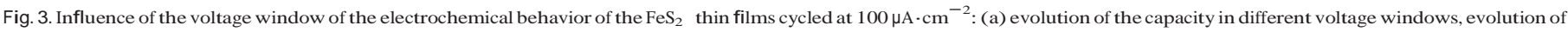

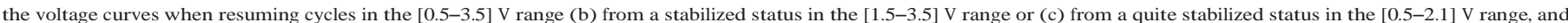

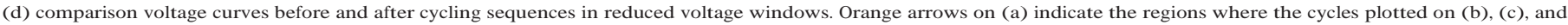
(d) were recorded. (For interpretation of the references to color in this figure legend, the reader is referred to the web version of this article.) 
The reversibility of the two electrochemical processes taking place respectively in the high voltage $[1.5-3.5 \mathrm{~V}]$ and the low voltage [0.5-2.1 V] vs $\mathrm{Li}^{+} / \mathrm{Li}$ regions was then evaluated separately (Fig. 3). Starting from the steady electrochemical behavior obtained in the full voltage range, the lower cut-off voltage was then raised from 0.5 to $1.5 \mathrm{~V} / \mathrm{Li}^{+} / \mathrm{Li}$ to operate the electrode only in the $\mathrm{FeS}_{2}-\mathrm{Li}_{2} \mathrm{FeS}_{2}$ compositional range. After few cycles in the high voltage window, the capacity is stabilizing at around half of the total capacity $\left(348 \mathrm{~mA} \mathrm{~h} \cdot \mathrm{g}^{-1}\right)$ and the coulombic efficiency remains unchanged and close to $100 \%$ (Fig. 3a). Compared to the shape of the full voltage curve, the one of the stabilized curve in the high voltage region (cycle \#554) is slightly modified, with a reduction of the polarization at the beginning of the charge and a displacement to a higher voltage at low state of charge. Further on, when resuming cycling in the full voltage range, the initial shape is perfectly and rapidly recovered in less than 10 cycles.

On the contrary, starting from a similar stabilized status in the full voltage range, a continuous operation in the low voltage region (i.e. initially between $\mathrm{Li}_{2} \mathrm{FeS}_{2}-2 \mathrm{Li}_{2} \mathrm{~S}+\mathrm{Fe}$ compositions) is clearly detrimental to the capacity retention (Fig. $3 \mathrm{a}, \mathrm{c}$ ) since the latter rapidly falls down from 340 to $200 \mathrm{~mA} \mathrm{~h} \cdot \mathrm{g}^{-1}$. This capacity fade is accompanied by a coulombic efficiency significantly higher than $100 \%$, indicating a limitation of the lithium deinsertion process compared to the insertion one. This behavior is connected to a progressive increase of the deinsertion potential (see cycle \#784) which can be mainly attributed to an increase of the concentration polarization, as the ohmic drop at the end of the charge remains quite constant $(\sim 32 \mathrm{mV})$. Besides, the resumption of cycling in the full voltage window (i.e. changing again the lower cut-off voltage from 1.5 to $0.5 \mathrm{~V} / \mathrm{Li}^{+} / \mathrm{Li}$ ) rapidly leads to the perfect recovery of the initial steady electrochemical behavior (Fig. 3d); meaning that the electrode material was not damaged during the prolonged operation. These observations finally suggest that only the distribution of the reactive species involved in the conversion reaction progressively changes inside the electrode film. Thus, two main phenomena are likely to lead to the capacity fade observed in the conversion reaction region: the segregation of the more oxidized product(s) near the electrode/electrolyte interface $\left(\mathrm{Li}_{2}+{ }_{x} \mathrm{FeS}_{2}\right.$ composition at the expense of $2 \mathrm{Li}_{2} \mathrm{~S}+\mathrm{Fe}$ ) inducing an increasingly positive concentration polarization during the succession of charges and preventing from fully recovering the $\mathrm{Li}_{2} \mathrm{FeS}_{2}$ composition at the end of the charge $\left(2.1 \mathrm{~V} / \mathrm{Li}^{+} / \mathrm{Li}\right)$ and/or a progressive increase of the size of the $\mathrm{Li}_{2} \mathrm{~S}$ and/or Fe domains leading to a less imbricated network, thus impeding the transport of species and the kinetics of the re-conversion reaction [17].

\section{Conclusion}

For the first time, all-solid-state lithium batteries using pyrite thin film electrodes were prepared and electrochemically characterized. In this cell configuration which inhibits the solubilization of sulfide intermediates occurring in liquid electrolyte and allows the maintenance of the integrity of the monolithic stack despite the large and repeated volume changes of the electrode material, pyrite thin films exhibit a high capacity $\left(\sim 830 \mathrm{~mA} \mathrm{~h} \cdot \mathrm{g}^{-1}\right.$ and $\left.3300 \mathrm{~mA} \mathrm{~h} \cdot \mathrm{cm}^{-3}\right)$ with almost no irreversible capacity during the first cycle (b2\%) and an excellent cycle life ( $-2.5 \%$ after 500 cycles). Hence, it is a very promising positive electrode material for all-solid-state thin film batteries. Besides, the perfect stability of its electrochemical behavior in these solid state cells allowed highlighting a progressive detrimental evolution of the electrochemical response when the electrode is operated only in the conversion reaction domain. The associated capacity fade, which can be erased by a complete lithium deinsertion, is likely to originate from a slow coarsening of the phase distribution which hinders the kinetics of the reverse conversion reaction. This phenomenon will have to be considered for the practical use of not only cells using pyrite, but possibly also other electrode materials involving conversion reaction with lithium.

\section{References}

[1] J.B. Bates, N.J. Dudney, D.C. Lubben, G.R. Gruzalski, B.S. Kwak, X. Yu, R.A. Zuhr, Thin-film rechargeable lithium batteries, J. Power Sources 54 (1995) 58-62, http://dx.doi.org/ 10.1016/0378-7753(94)02040-A.

[2] B. Wang, J.B. Bates, F.X. Hart, B.C. Sales, R.A. Zuhr, J.D. Robertson, Characterization of thin-film rechargeable lithium batteries with lithium cobalt oxide cathodes, J. Electrochem. Soc. 143 (1996) 3203-3213, http://dx.doi.org/10.1149/1.1837188.

[3] J. Cabana, L. Monconduit, D. Larcher, M.R. Palacin, Beyond intercalation-based Li-ion batteries: the state of the art and challenges of electrode materials reacting through conversion reactions, Adv. Mater. 22 (2010) E170-E192, http://dx.doi.org/10.1002/ adma.201000717.

[4] Y. Shao-Horn, S. Osmialowski, Q.C. Horn, Reinvestigation of lithium reaction mechanisms in $\mathrm{FeS}_{2}$ pyrite at ambient temperature, J. Electrochem. Soc. 149 (2002) A1547-A1555, http://dx.doi.org/10.1149/1.1516772.

[5] R. Fong, J.R. Dahn, C.H.W. Jones, Electrochemistry of pyrite-based cathodes for ambient temperature lithium batteries, J. Electrochem. Soc. 136 (1989) 3206-3210, http:// dx.doi.org/10.1149/1.2096426.

[6] T.A. Yersak, H.A. Macpherson, S.C. Kim, V.D. Le, C.S. Kang, S.B. Son, Y.H. Kim, J.E. Trevey, K.H. Oh, C. Stoldt, S.H. Lee, Solid state enabled reversible four electron storage, Adv. Energy Mater. 31 (2012) 120-127, http://dx.doi.org/10.1002/aenm.201200267.

[7] R. Brec, E. Prouzet, G. Ouvrard, Redox processes in the $\mathrm{Li}_{\mathrm{x}} \mathrm{FeS}_{2} / \mathrm{Li}$ electrochemical system studied through crystal, Mössbauer, and EXAFS analyses, J. Power Sources 26 (1989) 325-332, http://dx.doi.org/10.1016/0378-7753(89)80142-9.

[8] V. Yufit, K. Freedman, M. Nathan, L. Burstein, D. Golodnitsky, E. Peled, Thin-film iron sulfide cathodes for lithium and Li-ion/polymer electrolyte microbatteries, Electrochim. Acta 50 (2004) 417-420, http://dx.doi.org/10.1016/j.electacta.2004.01.104.

[9] H. Siyu, L. Xinyu, L. QingYu, C. Jun, Pyrite film synthesized for lithium-ion batteries, J. Alloys Compd. 472 (2009) L9-L12, http://dx.doi.org/10.1016/j.jallcom.2008.04.058.

[10] E. Strauss, D. Golodnitsky, K. Freedman, A. Milner, E. Peled, To the electrochemistry of pyrite in Li/solid composite-polymer-electrolyte battery, J. Power Sources 115 (2003) 323-331, http://dx.doi.org/10.1016/S0378-7753(03)00013-2.

[11] B. Fleutot, B. Pecquenard, F. Le Cras, B. Delis, H. Martinez, L. Dupont, D. Guy-Bouyssou, Characterization of all-solid-state $\mathrm{Li} / \mathrm{LiPONB} / \mathrm{TiOS}$ microbatteries produced at the pilot scale, J. Power Sources 196 (2011) 10289-10296, http://dx.doi.org/10.1016/ j.jpowsour.2011.07.018.

[12] G. Brostigen, A. Kjekshus, Redetermined crystal structure of $\mathrm{FeS}_{2}$ (pyrite), Acta Chem. Scand. 23 (1969) 2186-2188, http://dx.doi.org/10.3891/acta.chem.scand 23-2186

[13] H. Vogt, T. Chattopadhyay, H.J. Stolz, Complete first-order Raman spectra of the pyrite structure compounds $\mathrm{FeS}_{2}, \mathrm{MnS}_{2}$ AND $\mathrm{SiP}_{2}$, J. Phys. Chem. Solids 44 (1983) 869-873, http://dx.doi.org/10.1016/0022-3697(83)90124-5.

[14] J.R. Ares, A. Pascual, I.J. Ferrer, C.R. Sánchez, Lattice intrinsic defects and electrical resistivity in pyrite thin films, Thin Solid Films 451-452 (2004) 233-236, http:// dx.doi.org/10.1016/j.tsf.2003.10.102.

[15] R. Sun, M.K.Y. Chan, S.Y. Kang, G. Ceder, Intrinsic stoichiometry and oxygen-induced p-type conductivity of pyrite $\mathrm{FeS}_{2}$, Phys. Rev. B 84 (2011) 035212, http://dx.doi.org/ 10.1103/PhysRevB.84.035212.

[16] V.P. Phan, B. Pecquenard, F. Le Cras, High-performance all-solid-state cells fabricated with silicon electrodes, Adv. Funct. Mater. 22 (2012) 2580-2584, http://dx.doi.org/ 10.1002/adfm.201200104.

[17] F. Wang, R. Robert, N.A. Chernova, N. Pereira, F. Omenya, F. Badway, X. Hua, M. Ruotolo, R. Zhang, L. Wu, V. Volkov, D. Su, B. Key, M.S. Whittingham, C.P. Grey, G.G. Amatucci, Y. Zhu, J. Graetz, Conversion reaction mechanisms in lithium ion batteries: study of the binary metal fluoride electrodes, J. Am. Chem. Soc. 133 (2011) 18828-18836, http:// dx.doi.org/10.1021/ja206268a. 